\author{
Charlotte Searle
}

\author{
Professor and Head, \\ Department of Nursing Science, \\ University of South Africa
}

\section{Charlotte Searle}

\author{
Professor en Hoof, \\ Departement Verpleegkunde, \\ Universiteit van Suid-Africa
}

$\mathbf{T}$ his issue of CURATIONIS is concerned with a variety of important matters in contemporary nursing.

The profession is conscious of its need to examine the particular problems of the adolescent in society and of the adolescents in their own ranks. The main article in this issue is devoted to this subject. It provideds much food for thought for all registered nurses involved in health care of the adolescent. It is of particular concern to nurse administrators and nurse educators who play such an important part in the lives of student and pupil nurses and of young, newly qualified nurse practitioners.

It is necessary to re-examine and to update scine of the existing administrative and educational concepts in nursing, as well as to acquire greater knowledge about evolving roles of nurses in certain clinical areas. Thought provoking articles on some aspects of these topics are included in this issue.

As a licensed practitioner the midwife has been a familiar figure in South Africa since 1652. In this issue the spotlight falls on her contemporary role.

All health care professionals need to assess their attitude towards, and their knowledge of, the phenomenon called pain. The article on this subject should be read in conjunction with the articles dealing with the psycho - social pain and trauma found in children who have been hospitalised and in persons who are the victims of cancer, or who have a neurogenic bladder, for pain has both physical and emotional dimensions.

Some of the major problems in contemporary nursing relate to the problems of the practising nurse who is married. With seven out of ten practising registered nurses fulfilling the triple role of wife, mother and nurse practitioner it is clear that this is the most important problem nursing management has to contend with and which requires an innovative approach.

The high marriage rate of nurses within a hospital system that has traditionally based its nursing system on the employment of spinsters lies at the core of the problem of the shortage of nurses in a country that has one of the most favourable ratios of nurses to population in the world.

Much emphasis is at present placed on preventive and promotive aspects of health care. This is regarded as a priority approach - a very "with it" approach. But is this the case? The article on health care in the Bible and the Talmud emphasizes that this is a very ancient concept.
$\mathbf{H}$ ierdie uitgawe van CURATIONIS handel oor 'n verskeidenheid belangrike sake in die hedendaagse verpleging.

Die beroep is bewus van sy behoefte om die besondere probleme van die adolessent in die gemeenskap en die adolessent in sy eie geledere te ondersoek. Die belangrikste artikel in die uitgawe word aan dié onderwerp gewy. Dit bied stof tot nadenke aan alle geregistreerde verpleegkundiges wat met gesondheidsorg vir die adolessent gemoeid is. Dit is veral van belang vir verpleegadministreerders en -opvoeders wat so ' $n$ belangrike rol in die lewes van verpleegstudente en leerlingverpleegsters speel.

Dit is noodsaaklik om sommige van die administratiewe en opvoedkundige begrippe in verpleging weer te ondersoek en ook om meer kennis oor die ontwikkelende rol van die verpleegster in sekere kliniese gebiede op te doen. Die uitgawe bevat prikkelende artikels oor enkele aspekte van dié onderwerp.

Sedert 1652 was die vroedvrou as gelisensieerde praktisyn ' $n$ bekende figuur in Suid-Afrika. In hierdie uitgawe val die klem op haar eietydse rol.

Alle gesondheidsorg-professioneles moet hulle houding teenoor en hulle kennis van die verskynsel pyn bepaal. Die artikel oor die onderwerp moet nie geïsoleerd gelees word nie. Dit moet saam met die artikels gelees word wat oor psigo - sosiale pyn en trauma by gehospitaliseerde kinders handel asook by mense wat slagoffers van kanker is of 'n neurogene blaas het, want pyn het sowel fisiese as emosionele dimensies.

Sommige van die belangrikste probleme van eietydse verpleging hou met die probleem van die praktiserende getroude verpleegster verband. Waar sewe uit tien praktiserende geregistreerde verpleegkundiges die drievoudige rol van vrou, moeder en verpleegpraktisyn moet vervul, is dit duidelik die grootste probleem waarmee verpleegbeheer te kampe het en wat 'n nuwe benadering vereis.

Die kern van die probleem i.v.m. die tekort aan verpleegsters in 'n land met een van die hoogste verhoudings van verpleegsters tot bevolking in die wêreld, is die hoë huweliksyfer van verpleegsters binne 'n hospitaalstelsel wat sy verpleegstelsel tradisioneel op die indiensneming van ongetroude vroue gegrond het.

Vandag word daar baie klem op die voorkomende en bevorderende aspekte van verpleegsorg gelê. Dit word as 'n prioriteitsbenadering beskou - 'n baie "byderwetse" benadering. Maar is dit so? Die artikel oor gesondheidsorg in die Bybel en die Talmoed beklemtoon dat dit ' $n$ baie ou begrip is. 
Finally the article on the role of the Wellcome organization reminds us of the important role that some of the great pharmaceutical and medical supply houses have played in the development of health services. Without their sustained and thorough research and their generous financial support health care would not be as advanced as it is today.
Ten slotte laat die artikel oor die rol van die Wellcome-organisasie ons dink aan die belangrike rol wat enkele van die groot farmaseutiese en mediese firmas in die uitbou van gesondheidsdienste gespeel het. Sonder hulle volgehoue, deeglike navorsing en ruime geldelike hulp sou gesondheidsorg nie so ver gevorderd gewees het as wat dit vandag is nie. 